\title{
Viktoriia Hudy*
}

iD https://orcid.org/0000-0003-0864-0566

\section{CZY ROSYJSKI JEST BARDZIEJ „ANGIELSKI” NIŻ POLSKI? O ZAPOŻYCZENIACH W JEZZYKU INFORMATYCZNYM W ASPEKCIE GLOTTODYDAKTYCZNYM}

Słowa kluczowe: język specjalistyczny, zapożyczenia, język informatyczny

Streszczenie. Dzięki powszechnej globalizacji specjaliści z różnych dziedzin, zwłaszcza wysoko wykwalifikowani, mogą bez problemu znaleźć zatrudnienie poza granicami swojego kraju. Polska znajduje się wśród państw, których rynek pracy jest coraz bardziej atrakcyjny dla wielu cudzoziemców. Dotyczy to także branży IT, od lat przyciągającej specjalistów z krajów byłego Związku Radzieckiego. Interesujące jest zatem - wydaje się - porównanie wpływu języka angielskiego, będącego podstawą języka specjalistycznego tej branży, na język polski i rosyjski.

W artykule autorka podejmuje próbę odpowiedzi na pytanie, czy anglicyzmy występujące w polskim i rosyjskim języku informatycznym są takie same. Pragnie także pokazać stopień przyswojenia przykładowych zapożyczeń w obu omawianych językach i omówić wynikające z tych obserwacji implikacje dla glottodydaktyki polonistycznej.

Polska staje się coraz atrakcyjniejszym rynkiem pracy dla cudzoziemców, o czym świadczą raporty Ministerstwa Rodziny, Pracy i Polityki Społecznej (MRPiPS). Firmy polskie chętnie zatrudniają obcokrajowców głównie zza wschodniej granicy. Dotyczy to także branży IT. Dzieje się tak przede wszystkim dlatego, że firmy z sektora IT mają obecnie duży problem ze zdobyciem wykwalifikowanych polskich pracowników. Z najnowszych danych firmy Sedlak \& Sedlak wynika, że w Polsce brakuje obecnie około 50 tysięcy fachowców ${ }^{1}$. Wolnych etatów jest więc o wiele więcej niż specjalistów skłonnych podjąć pracę w zawodzie. Powodem tego jest szybka dynamika rozwoju branży IT oraz niż demograficzny lat

*viktoriia.hudy@gmail.com, Uniwersytet Marii Curie-Skłodowskiej w Lublinie, Wydział Humanistyczny, Centrum Języka i Kultury Polskiej dla Polonii i Cudzoziemców, plac Marii Skłodowskiej-Curie 5, 20-031 Lublin.

${ }^{1}$ Zob.: www.rp.pl/artykul/1122154-Brakuje-informatykow--Deficyt-siega-50-tys-specja-list -ow [4.04.2018]. 
90. - absolwenci kierunków informatycznych nie są w stanie wypełnić powstałej luki, gdyż jest ich za mało. Rozwiązaniem problemu może stać się zatrudnianie wykwalifikowanych cudzoziemców. Według danych MRPiPS systematycznie rośnie liczba oświadczeń o zamiarze zatrudnienia, wydawanych obcokrajowcom przez firmy IT (w 2012 roku było ich 460, rok później 686, w 2014 roku - 3227, w 2017 - ok. 5000)². Warto przy tym zaznaczyć, iż zdecydowana większość takich dokumentów wydawanych przez firmy IT dotyczyła obywateli państw byłego Związku Radzieckiego, głównie Ukraińców, Rosjan oraz Białorusinów. Te grupy narodowościowe $\mathrm{w}$ pełni spełniają oczekiwania polskiego pracodawcy. Specjaliści ze Wschodu to osoby posiadające wykształcenie wyższe, doświadczenie w branży IT oraz wykazujące się dobrą znajomością języka angielskiego, bo to właśnie ten język jest podstawą pracy w omawianym sektorze. Nic zatem dziwnego, że zarówno w polskim, jak i rosyjskim języku informatycznym ${ }^{3}$, pojawiło się wiele zapożyczeń z angielszczyzny. Czy jednak anglicyzmy ${ }^{4}$ te są takie same? W jaki sposób dokonuje się transfer leksyki z języka angielskiego do języka polskiego i rosyjskiego? Jakie ma to znaczenie w nauczaniu polskiego języka specjalistycznego? Niniejszy artykuł jest próbą odpowiedzi na postawione wyżej pytania.

W obu językach obserwujemy dużą liczbę zapożyczeń anglojęzycznych z dziedziny IT. Definicja tego terminu w Nowym słowniku poprawnej polszczyzny brzmi: „Zapożyczenia to obce w strukturze danego języka wyrazy, zwroty, typy derywatów, formy fleksyjne, konstrukcje składniowe, związki frazeologiczne" (Nowy słownik... 1999, s. 1773). Od średniowiecza po czasy współczesne różne języki miały wpływ na zasoby leksykalne zarówno języka polskiego, jak i rosyjskiego. Zapożyczenia $\mathrm{w}$ języku polskim pochodzą przede wszystkim z łaciny (atrament, cynamon, mandat, metryka), języka niemieckiego (baszta, cukier, druk, fatsz, handel, gatunek, koszt, sztuka), francuskiego (adres, awans, bagaż, balon, basen, biżuteria, dama), czeskiego (anioł, msza, papież, ottarz, starosta, mistrz), włoskiego (kalafior, sałata, bankiet, fontanna), rosyjskiego (bałagan, czajnik, kombajn, kufajka) oraz ukraińskiego i białoruskiego (błahy, chata, hulać, morda, ruczaj) (Witaszek-Samborska 1992, s. 53-55). Nieco w mniejszym stopniu na polszczyznę oddziaływały języki orientalne, głównie turko-tatarskie (bisurmanin, buława, kaleta, szarawary) (Walczak 1987, s. 19).

W języku rosyjskim można zaobserwować silne wpływy następujących języków: staro-cerkiewno-słowiańskiego (бог, грех, жертва, блуд), łaciny (формула,

\footnotetext{
${ }^{2}$ Zob.: www.bankier.pl/wiadomosc/Cudzoziemcy-w-Polsce-przybywa-informatykow-medykow-i-specjalistow, [4.04.2018].

${ }^{3}$ Celem artykułu jest próba porównania podstawowego słownictwa informatycznego w języku polskim oraz rosyjskim, ponieważ to właśnie tym ostatnim jako językiem pierwszym (Rosja, Białoruś) lub drugim (Ukraina) posługuje się większość obywateli państw byłego bloku wschodniego.

${ }^{4} \mathrm{Za}$ anglicyzmy uznaję zarówno zapożyczenia z języka angielskiego brytyjskiego oraz angielskiego amerykańskiego.
} 
экзамен, цирк, литература, канцелярия), greckiego (грамота, парус, палата, ангел, икона, алфавит), niemieckiego (контора, пакет, прейскурант, лагерь, штаб, командир, офицер, бутерброд), francuskiego (салон, лакей, генерал, лейтенант, сеанс, одеколон, вуаль, котлета), polskiego (булка, вензель, краковяк), włoskiego (тенор, ария, ложа, дуэт, купол, арка) (Šanskij 2009, s. 109-112). Znaczący wpływ na kształtowanie się języka rosyjskiego miały również wyrazy pochodzące z języków turkijskich (башка, караул, казна) (Erova 2017, s. 1). Okazjonalnie w języku rosyjskim pojawiły się zapożyczenia z języka ukraińskiego, czeskiego, węgierskiego, hiszpańskiego, chińskiego, japońskiego (Šanskij 2009, s. 112).

Brak bezpośredniej styczności oraz bliskich kontaktów zAnglią spowodowały, iż do końca XIX w. zapożyczenia z języka angielskiego w języku polskim i rosyjskim pojawiały się jedynie sporadycznie. Wpływ angielszczyzny zaczął się zwiększać pod koniec XIX i na początku XX w. wraz ze wzrostem znaczenia Wielkiej Brytanii na arenie międzynarodowej (Luciński 2000, s. 9; Walczak 1987, s. 21). Rozwój kontaktów gospodarczych, politycznych oraz kulturalnych Anglii z Polską i Rosją spowodował, że język angielski w XX wieku stał się głównym źródłem zapożyczeń dla języka polskiego i rosyjskiego (Luciński 2000, s. 8).

Podczas II wojny światowej w obu językach pojawiły się nowe, podobne wyrazy związane przede wszystkim z działaniami wojennymi, np. - w języku polskim: bazooka, dum-dum, napalm, snajper, sten, tankietka, w rosyjskim: базука, дум-дум, напалм, снайпер, стэн, танкетка (Luciński 2000, s. 17). Większość tych wyrazów wyszła już z aktywnego użycia.

Po II wojnie światowej ${ }^{5}$ wpływ angielszczyzny staje się coraz większy. Coraz silniejsza pozycja języka angielskiego jako języka światowego spowodowała, że do współczesnego języka polskiego i rosyjskiego masowo przenikają wyrazy z zakresu terminologii technicznej i naukowej, a zwłaszcza z cybernetyki, np. pol.: algol, bit, cobol, komputer, ros.: алгол, бит, кобол, компьютер czy elektroniki, np. pol.: bewatron, kriotron, laser, maser, tranzystor, ros.: беватрон, криотрон, лазер, мазер, транзистор (Luciński 2000, s. 18). Duży napływ nowej leksyki związany jest z kategorią urządzeń technicznych i maszyn, np. pol.: adapter, bojler, buldożer, kontener, skaner, ros.: адаптер, бойлер, бульдозер, контейнер, сканер oraz procesów technologicznych, $n p$. w pol.: flotacja, honingowanie, kraking, w ros.: флотаиия, хонингование, крекинг. Do obu języków przedostało się także słownictwo z zakresu motoryzacji, np. w pol.: skuter, trolejbus, autobus, jeеp, tuning, w ros.: скутер, троллейбус, джип, тюнинг. Dziedziną, która także w tym okresie wywarła duży wpływ na polski i rosyjski zasób słownictwa była moda. Skutkowało to pojawieniem się nowego słownictwa, np. w pol.: dżinsy, bikini, szorty, w ros.: джинсы, бикини, шорты. Zainteresowanie anglo-amerykańską

${ }^{5}$ Elżbieta Mańczak-Wohlfeld II wojnę światową uznaje za cezurę między starszymi i nowszymi wpływami języka angielskiego na polszczyznę (Mańczak-Wohlfeld 2006, s. 42). 
kulturą spowodowało duży napływ nowego słownictwa $\mathrm{z}$ dziedziny szeroko pojętej sztuki współczesnej, np. w pol.: blues, hip-hop, breakdance, remake, casting, pop-art, fantasy, w ros.: блюз, хип-хоп, брейк-данс, ремейк, кастинг, поп-арт, фэнтези. Wiele zapożyczeń dotyczy produktów żywnościowych, potraw czy napojów, np. w pol.: coca-cola, keczup, whisky, chipsy, hamburger, hot-dog, w ros.: кока-кола, кетчуп, виски, чипсы, гамбургер, хот-дог (Dunin-Dudkowska 2013, s. 194).

Pod koniec XX wieku w państwach bloku wschodniego nastąpiły istotne zmiany ekonomiczne, polityczne oraz społeczne, które spowodowały kolejny, szeroki napływ zapożyczeń angielskich. W języku polskim i rosyjskim pojawiło się słownictwo z zakresu gospodarki rynkowej (zwłaszcza bankowości), takie jak: pol. broker, makler, holding, leasing, marketing, manager, know-how, ros. брокер, маклер, холдинг, лизинг, маркетинг, менеджер, ноу-хау (Luciński 2000, s. 18).

Szczególnie dużo nowych zapożyczeń dotyczy języka informatycznego. Warto byłoby zastanowić się nad przyczynami tego zjawiska. Według Leonida Krysina na transfer językowy mają wpływ przyczyny wewnętrzne oraz zewnętrzne. Do przyczyn wewnętrznych badacz zalicza: potrzebę nazywania nowych zjawisk oraz rzeczy, konieczność rozróżnienia słów bliskoznacznych, tendencję polegającą na tym, że konkretne zjawisko, rzecz warto nazywać jednym wyrazem a nie związkiem wyrazowym (Krysin 2004, s. 27-30). Do przyczyn zewnętrznych należą bardziej lub mniej aktywne relacje polityczno-ekonomiczne, naukowe, kulturalne czy społeczne pomiędzy różnymi narodami (Krysin 2004, s. 26).

Sektor IT jest przykładem najbardziej mobilnej branży. Firmy, które do niej należą, to firmy globalne, rozrzucone po całym świecie. Dzięki niezwykle dynamicznemu rozwojowi współczesnej technologii współpracują one ze sobą ponad granicami państw. Jest to jednocześnie branża, w której językiem prymarnym jest angielski, który zajmuje czołowe miejsce na liście języków światowych. W nim bowiem pisze się literaturę przedmiotową czy większość programów komputerowych. Klientem docelowym jest zatem bardzo często osoba lub grupa osób znających język angielski. Ponadto, największe korporacje czy centra informatyczne (także badawcze) znajdują się w Stanach Zjednoczonych. Dlatego wpływ języka angielskiego na system leksykalny innych języków jest czymś oczywistym, a poza tym - leksyka to podsystem najbardziej otwarty na różnego rodzaju wpływy zewnętrzne. To w podsystemie leksykalnym najszybciej odzwierciedlają się wszystkie zmiany, które zachodzą w danym społeczeństwie. Najczęściej spotykaną formą wpływów zewnętrznych są zapożyczenia jednostek leksykalnych razem z przedmiotami i zjawiskami, które dane zapożyczenie nazywa, co jednocześnie prowadzi często do powstawania wyrazów lub wyrażeń ekwiwalentnych do już istniejących w języku ojczystym. Zjawisko to można zaobserwować zarówno w polskim języku informatycznym, jak i w rosyjskim, np.,: w pol.: bug lub bład w programie, zrobić back up lub wykonać kopię zapasowa; w ros.: юзер 
lub пользователь, левел lub уровень, апликейшн lub приложение, девайс lub устройство. Warto zauważyć, iż w języku rosyjskim formy ekwiwalentne występują o wiele częściej niż w języku polskim, przy czym anglicyzmy są używane przez specjalistów zdecydowanie chętniej.

Według Krysina duże znaczenie dla akceptacji zapożyczeń mają również czynniki społeczno-psychologiczne: zapożyczenia są często postrzegane przez użytkowników języka jako bardziej „prestiżowe” oraz „lepiej brzmiące” (Krysin 1996, s. 58). Wpływ tych czynników na rosyjski język specjalistyczny jest bardziej zauważalny niż w języku polskim.

Jak już wspomniano wcześniej, zapożyczenia angielskie występują zarówno w języku polskim, jak i rosyjskim, jednak proces transferu leksyki informatycznej do obu języków znacznie się od siebie różni. Można to prześledzić, porównując zestawienie znajdujące się $\mathrm{w}$ poniższej tabeli. Wyrazy $\mathrm{w}$ niej umieszczone są wynikiem krótkiej ankiety przeprowadzonej wśród pracowników rosyjskojęzycznych i polskojęzycznych branży IT. Ankieta dotyczyła listy słów najczęściej używanych w pracy. Jest ona także efektem własnych obserwacji autorki oraz analizy słowników przedmiotowych a także podręczników i poradników pomagających opanować słownictwo zawodowe. Uczący się (specjaliści branży IT) zostali poproszeni o stworzenie listy najczęściej używanych słów w pracy w języku angielskim oraz dopisanie odpowiednika w swoim rodzimym języku. W ankiecie wzięło udział 30 informatyków narodowości wschodniosłowiańskiej (15 Ukraińców, 10 Rosjan oraz 5 Białorusinów). Warto podkreślić, że były to osoby posługujące językiem rosyjskim. Ankietę wypełniło również 30 informatyków narodowości polskiej. Słowa o najwyższej frekwencji zostały umieszczone w poniższej tabeli. Należy przy tym zauważyć, iż wiele zapożyczeń z języka angielskiego funkcjonujących w rosyjskim języku informatycznym nie zostało jeszcze ujętych w słownikach obu języków, co wcale nie świadczy o rzadkości ich występowania, lecz o nowości oraz hermetyczności ich użycia, ograniczonego głównie do języka specjalistów z IT.

Tabela 1. Zestawienie terminów informatycznych w języku angielskim, polskim i rosyjskim

\begin{tabular}{|c|c|c|c|}
\hline Lp. & angielski & polski & rosyjski \\
\hline \multicolumn{4}{|c|}{ Czasowniki } \\
\hline 1 & to back up & $\begin{array}{l}\text { zrobić back up / } \\
\text { wykonać kopię zapasową }\end{array}$ & $\begin{array}{l}\text { забекапить / сделать } \\
\text { резервное копирование }\end{array}$ \\
\hline 2 & to save & zapisać/zasejwować & засейвить/сохранять \\
\hline 3 & to fix & naprawić, sprawdzać & фиксить/исправлять \\
\hline 4 & to delete & skasować, usunąć & делетнуть/удалить \\
\hline 5 & to click & kliknąć & кликнуть \\
\hline 6 & to connect & połączyć się & законнектиться \\
\hline 7 & to upgrade & podnosić jakość / upgradować & апгрейд/апгрейдить \\
\hline
\end{tabular}




\begin{tabular}{|c|c|c|c|}
\hline Lp. & angielski (cd.) & polski (cd.) & rosyjski (cd.) \\
\hline 8 & to download & ściągać (np. pliki z internetu) & $\begin{array}{l}\text { даунлоадить / скачивать } \\
\text { файлы }\end{array}$ \\
\hline 9 & to update & aktualizować / updatować & заапдейтить/обновить \\
\hline 10 & to debug & usuwać błędy w programie & дебажить \\
\hline 11 & to build & $\begin{array}{l}\text { budować (w programowaniu, } \\
\text { proces łączenia czy } \\
\text { kompilacji kodu, czyli } \\
\text { budowania aplikacji) }\end{array}$ & билдить \\
\hline 12 & to deploy & używać, stosować & деплоить \\
\hline 13 & to compile & kompilować & компилить \\
\hline 14 & to approve & zatwierdzać & заапрувить/подтвердить \\
\hline 15 & to share & udostępnić & расшарить \\
\hline 16 & to code & kodować/programować & кодить \\
\hline 17 & to resolve & rozkładać/rozczepiać & резолвить \\
\hline 18 & to convert & konwertować/przekształcać & конвертить \\
\hline 19 & to $\log$ in & logować się & логиниться \\
\hline 20 & to upload & „wrzucić” (np. plik na serwer) & $\begin{array}{l}\text { аплоадить / закачивать } \\
\text { файлы на сервер }\end{array}$ \\
\hline 21 & to flood & $\begin{array}{l}\text { zalewać } \\
\text { (metoda wyboru trasy) }\end{array}$ & флудить \\
\hline \multicolumn{4}{|c|}{ Rzeczowniki } \\
\hline 22 & bug & błąd w programie / bug & баг \\
\hline 23 & user & użytkownik & юзер/пользователь \\
\hline 24 & device & urządzenie & девайс/устройство \\
\hline 25 & content & treść, zawartość & контент \\
\hline 26 & file & plik & файл \\
\hline 27 & cookie & ciasteczko & куки \\
\hline 28 & desktop & pulpit/desktop & рабочий стол / десктоп \\
\hline 29 & browser & przeglądarka & браузер \\
\hline 30 & site & strona & сайт \\
\hline 31 & server & serwer & сервер \\
\hline 32 & account & konto & аккаунт \\
\hline 33 & application & aplikacja & приложение/апликейшн \\
\hline 34 & attachment & załącznik & $\begin{array}{l}\text { аттач / файл прикрепленный } \\
\text { к электронному письму }\end{array}$ \\
\hline 35 & keygen & keygen & кейген \\
\hline 36 & default & $\begin{array}{l}\text { parametr standardowy, } \\
\text { parametr przyjmowany } \\
\text { domyślnie }\end{array}$ & дефолт \\
\hline
\end{tabular}




\begin{tabular}{|c|c|c|c|}
\hline Lp. & angielski (cd.) & polski (cd.) & rosyjski (cd.) \\
\hline 37 & hr-manager & $\begin{array}{l}\text { kierownik ds. personalnych / } \\
\text { manager zasobów ludzkich }\end{array}$ & $\begin{array}{l}\text { эйчар / менеджер по } \\
\text { персоналу }\end{array}$ \\
\hline 38 & level & poziom & левел/уровень \\
\hline 39 & production & produkcja & продакшн \\
\hline 40 & script & skrypt & скрипт \\
\hline 41 & uptime & czas sprawności & аптайм \\
\hline 42 & meeting & spotkanie & митинг \\
\hline 43 & demo & program pokazowy / demo & демо/демка \\
\hline 44 & owner & właściciel & овнэр/владелец \\
\hline 45 & task & zadanie & таск/таска/задача \\
\hline 46 & issue & problem & ишью/проблема \\
\hline 47 & feature & właściwość & фича \\
\hline 48 & kernel & jądro/rdzeń & кэрнел \\
\hline 49 & customer & klient & кастомер \\
\hline 50 & framework & $\begin{array}{l}\text { framework / platforma } \\
\text { programistyczna }\end{array}$ & фреймворк \\
\hline 51 & call & połączenie & кол \\
\hline 52 & review & przegląd & ревью \\
\hline 53 & planning & planowanie & планнинг \\
\hline 54 & screenshot & $\begin{array}{l}\text { zdjęcie ekranu / zrzut ekranu } \\
\text { / screen }\end{array}$ & скриншот \\
\hline 55 & profile & profil & профайл \\
\hline 56 & permission & dostęp & пермишн \\
\hline 57 & header & nagłówek & хедер \\
\hline \multicolumn{4}{|c|}{ Przymiotniki/Imiesłowy } \\
\hline 58 & binary file & plik binarny & бинарный файл / бинарник \\
\hline 59 & offline & offline/rozłączony & оффлайн \\
\hline 60 & native & rodzimy & нативный \\
\hline
\end{tabular}

Źródło: opracowanie własne

Na podstawie powyższej tabeli można wysnuć następujące wnioski: w języku polskim z 60 zbadanych wyrazów 26 to zapożyczenia z języka angielskiego, np. kliknać, kodować, logować się, aplikacja, z których 11 ma ekwiwalenty rodzime, np. zrobić back up - wykonać kopię zapasowa, upgradować-podnosić jakość, bug - błą, header-nagłówek. W języku rosyjskim z 60 analizowanych wyrazów 60 to anglicyzmy, np. кодить, флудить, файл, куки, ekwiwalenty rodzime ma 19 słów, np. заапдейтить - обновить, фиксить - исправлять, заапрувить - подтвердить, девайс -устройство. 
Z powyższego zestawienia próbki językowej wynika, iż we współczesnym języku rosyjskim anglicyzmy z dziedziny informatyki przyjmowane są na ogół w postaci częściowo lub całkowicie przyswojonej z zapisem fonetycznym cyrylicą - wyraz angielski zapisywany jest tak, jak jest wymawiany w języku angielskim lub podobnie, zaś jego znaczenie pozostaje bez zmian. Można więc przyjąć, że w tym zakresie język rosyjski jest bardziej ,angielski” niż polski, np., pol.: przegladarka, nagtówek, strona, udostępnić; ros.: браузер, хедер, сайm, pacmapumb. Można też zauważyć pewną specyficzną tendencję, a mianowicie: w języku rosyjskim w prezentowanej próbce najwięcej jest słów będących fonetycznym zapisem wyrazów angielskich. Stanowią one $56,6 \%$ porównywanych terminów. Grupę tę reprezentują przede wszystkim rzeczowniki, np.: file - файл, site - caŭm, level - левел, browser - браузер, permission - пермишн (por. pol.: plik, strona, poziom, przegladarka, dostęp). Wśród polskich słów, które byłyby fonetycznym odzwierciedleniem wyrazów angielskich odnotowano jedynie $10 \%$ zapożyczeń tego typu, np.: server-serwer, script-skrypt.

Kolejna grupa to wyrazy podobne do fonetycznego zapisu słów angielskich, lecz takie, w których zaszły pewne modyfikacje. W omawianej próbce w języku rosyjskim stanowią one $43,3 \%$, zaś w polskim - $16,6 \%$. Są to czasowniki, a zmiany, które w nich zachodzą, polegają najczęściej na dodawaniu do zapożyczonego tematu formantów sufiksalnych i/lub prefiksalnych. Prefiksem niejednokrotnie pojawiającym się w zestawieniu wyrazów rosyjskich jest $3 a$ - i ma on znaczenie 'doprowadzić działanie do pomyślnego zakończenia', por. nр.: засейвить, забекапить, законнектиться, заапдейтить, заапрувить. Sufiksem, który przeważa w przykładach rosyjskich jest $-u(m b), \mathrm{np} .:$ фиксить, дебажить, компилить, кодить, резолвить, конверить, флудить. Są to czasowniki całkowicie przyswojone podlegające pełnej fleksji języka rosyjskiego, np. дебажу, дебажишь; компилю, компилишь. W czasownikach polskich pojawia się natomiast często sufiks -owa(ć), który jest typowy dla zapożyczeń czasownikowych, por. np.: kompilować, kodować, programować, konwertować, logować się. Czasowniki te również są szybko przyswajane, podlegając polskiej fleksji czasownikowej, np. kompiluje, kompilujesz; koduje, kodujesz.

Wiedza na temat sposobów przyswajania zapożyczeń z języka angielskiego występujących w specjalistycznej leksyce informatycznej jest przydatna w nauczaniu języka polskiego osób zza wschodniej granicy. Dotyczy to zwłaszcza kursów i/lub zajęć językowych organizowanych dla przyszłych pracowników sektora IT oraz kandydatów na studia informatyczne w Polsce. Trudności z językiem polskim u osób rosyjskojęzycznych mogą wynikać z nieświadomej interferencji językowej: osoby takie próbują do języka polskiego, którego używają w kontaktach zawodowych, przenosić zapożyczoną terminologię specjalistyczną, która w języku rosyjskim w dużym stopniu brzmi tak samo jak w angielskim. Osobom takim wydawać się może, iż proces przyswajania zapożyczeń w polszczyźnie przebiega 
analogicznie do języka rosyjskiego. Brak świadomości uczących się o nieprawidłowości toku ich rozumowania może prowadzić do licznych nieporozumień, a więc negatywnie wpływać na jakość współpracy polskich i rosyjskojęzycznych specjalistów zatrudnionych w firmach IT. Można to zilustrować kilkoma przykładami autentycznych ${ }^{6}$ zdań:

- Pofiksowatem tego buga (ros.: Я пофиксил этот баг) zamiast poprawnie po polsku - Naprawitem ten btad;

- Trzeba zadeploić wszystkie zmiany na serwer (ros.: Нужно задеплоить все изменения на сервер zamiast poprawnie po polsku - Trzeba umieścić wszystkie zmiany na serwerze;

- Juzer na tym się nie zna. (ros.: Юзер в этом ничего не понимает) zamiast poprawnie po polsku - Użytkownik na tym się nie zna;

- Caty dzień musiałem poświęcić na ta taskę. (ros.: Я иельй день потратил на эту таску) zamiast poprawnie po polsku - Cały dzień poświęciłem na to zadanie.

Rosyjskojęzyczni specjaliści z branży IT wychodzą często z założenia, że skoro język angielski jest tu językiem prymarnym, a na dodatek w rosyjskim wiele wyrazów brzmi podobnie jak w angielszczyźnie, to nie powinno być problemów z komunikacją w języku polskim. Lektorzy języka polskiego jako obcego, ucząc w grupach, w których jest potrzebne wprowadzanie słownictwa specjalistycznego, muszą brać pod uwagę opisane wyżej różnice.

Leksykę zawodową warto utrwalać, sięgając po różnego typu techniki nauczania słownictwa, pamiętając przy tym, iż nowe słowa uczniowie przyswajają najlepiej, gdy występują one w naturalnym kontekście (Seretny, Lipińska 2005, s. 85 ). Techniki prezentacji nowej leksyki zawodowej mogą być podobne do tych, po które sięgamy, wprowadzając słownictwo ogólne. Nowy materiał leksykalny można wprowadzać na wiele sposobów, np. poprzez odwoływanie się synonimów, objaśnianie kontekstowe, prezentowanie definicji słownikowej, podawanie ekwiwalentu w języku rodzimym uczących lub/i w języku angielskim (por. Komorowska 2003 s. 116-117; Seretny, Lipińska 2005, s. 85). Techniki utrwalania nowego słownictwa zawodowego mogą się również opierać na sposobach tradycyjnych, $\mathrm{np} .:$ powtarzania nowego słowa $\mathrm{w}$ grupie oraz indywidualnie, układanie zdań lub/i mini-dialogów z wykorzystaniem nowych słów, odgrywanie mini-scenek komunikacyjnych z użyciem nowego słownictwa (Seretny, Lipińska 2005, s. 88). Żeby utrwalona leksyka zawodowa została zapamiętana, należy ją często powtarzać, sięgając po różnego typu ćwiczenia leksykalne, m.in. po takie jak:

${ }^{6}$ Przytoczone zdania pochodzą z wypowiedzi osób rosyjskojęzycznych uczących się JPJO. Osoby te pracują w Polsce w branży IT. 
- przyporządkowywanie słów do pewnych kategorii zgodnie z ustalonym wcześniej kryterium, np.:

klient, komputer, wykonać kopię rezerwową, połączyć się, kompilować, użytkownik, właściciel, blok systemowy, kliknąć, laptop, kierownik ds. personalnych

\begin{tabular}{|c|c|c|}
\hline URZĄDZENIA & CZYNNOŚCI & OSOBY \\
\hline PEREFERYJNE & & \\
& & \\
\hline
\end{tabular}

- poszukiwanie słowa, które kojarzy się z kilkoma podanymi wyrazami, np.:

graficzna, dźwiękowa, multimedialna - karta

równoległy, szeregowy - port

globalna, lokalna, miejska - sieć komputerowa

- wymienianie słów, będących leksykalnym wypełnieniem kategorii, np.:

\begin{tabular}{|c|}
\hline DANE \\
\hline baza danych \\
elektroniczne przetwarzanie danych \\
wprowadzanie danych \\
kompresja \\
dekompresja \\
odczyt \\
odzyskiwanie danych \\
\hline
\end{tabular}

- dopełnianie charakterystycznych połączeń (np. kolokacji), np.:

uruchomić, wykonać, ściągnąć

Po prawidłowo przeprowadzonej instalacji należy ............... program. Jeśli nie chcesz stracić swoich plików - musisz . . . . . . . . . . kopię zapasową. Młodzież coraz rzadziej wypożycza książki w bibliotece - większość lektur można już . . . . . . . . . . . . w Internecie.

\section{- opracowywanie siatek składniowo-semantycznych, np.:}

PROGRAM - licencjonowany, antywirusowy, użytkowy; instalowanie (instalacja) programu, uruchomienie programu, zamykać/zamknąć program; wersja programu; program obsługi. 
Warto również pamiętać, że zasób leksykalny naszych uczniów poszerzamy po to, by rozwijać ich sprawności językowe: mówienie, słuchanie, pisanie i czytanie (Seretny, Lipińska 2005, s. 100). Nie należy przy tym zapominać o sprawności mediacyjnej, której ważnym elementem jest tłumaczenie. Zadania translatoryczne są tu bowiem szczególnie przydatne. Godne uwagi są ćwiczenia typu:

- tworzenie słowniczków trójjęzycznych,

- uzupełnianie tabelek dwujęzycznych,

- thumaczenie pojedynczych zdań.

Lektor może też sięgać po thumaczenia tekstów specjalistycznych z angielskiego oraz rosyjskiego na polski lub odwrotnie: z języka polskiego na inne języki (angielski, rosyjski). Przy tworzeniu tego typu ćwiczeń nauczyciel może korzystać z osiągnięć językoznawstwa korpusowego. Uczący języka obcego może także tworzyć własne minikorpusy. Korzystając p.. z programu TextSTAT, lektor może gromadzić różnego rodzaju teksty równoważne, w których - w razie potrzeby - bez problemu będzie mógł wyszukać interesujące przykłady, zwroty, związki frazeologiczne (Krajka 2016, s. 36). Aktywizacja trzech języków (angielskiego, polskiego i rosyjskiego) powinna pomóc studentom w szybszym uświadomieniu sobie różnic znaczeniowych używanych zapożyczeń, co ma wpływ na skuteczność i poprawność komunikacji.

Posługiwanie się kilkoma językami powoduje, że wielu ukraińskich informatyków stosuje kalki językowe, przechodząc, często automatycznie, z jednego języka na drugi. Dzięki temu, że wielu polskich specjalistów z tej branży posługuje się językiem angielskim, Ukraińcy, stosujący w nadmiarze słownictwo anglojęzyczne, są jednak zwykle dobrze rozumiani przez swoich polskich partnerów. Problem może pojawić się wówczas, kiedy ich polscy współpracownicy nie znają języka angielskiego. Sytuację może dodatkowo komplikować fakt, iż informatycy z Ukrainy stosują profesjolekt rosyjski, ponieważ do tej pory nie wykształcił się jego ukraiński odpowiednik.

Wielojęzyczność ma wpływ na „przełączanie się” z języka polskiego na rosyjski, zwłaszcza wtedy, kiedy nadawca komunikatu nie zna danego terminu w języku polskim. Może to prowadzić do powstawania tzw. zdań-hybryd, w których pojawia się część słów rosyjskich i część polskich.

Wielojęzyczność informatyków, mówiących również po rosyjsku, z jednej strony ułatwia komunikację, gdyż stosowane przez nich kalki językowe czy też przełączanie się z języka na język sprawdza się w kontaktach z informatykami polskimi. Jednak z drugiej strony może utrudniać porozumiewanie się z osobami, np. klientami, nieznającymi rosyjskiego i angielskiego, tym bardziej, że zapożyczenia angielskie $\mathrm{w}$ języku rosyjskim są często wymawiane zgodnie $\mathrm{z}$ regułami fonetycznymi języka rosyjskiego. Nierzadko wielojęzyczność uczących się daje im złudzenie pewności, że jeśli są rozumiani przez Polaków, to znaczy, iż mówią po polsku. 
W związku z powyższym nauczyciel JPJO pracujący z ukraińskimi informatykami, powinien koncentrować się głównie na takich elementach leksykalnych, które mogą utrudniać lub uniemożliwiać komunikację z informatykami polskimi czy klientami biznesowymi. Nieznajomość polskiego języka informatycznego obniża bowiem nie tylko skuteczność komunikacji i wydajność pracy, ale wydłuża także czas wykonania poszczególnych zadań, co może mieć znaczący wpływ na karierę zawodową.

\section{BIBLIOGRAFIA}

Dunin-Dudkowska A., 2013, Zapożyczenia angielskie w polszczyźnie 70-lecia, w: A. Dunin-Dudkowska, A. Małyska (red.), 70 lat polszczyzny. Zjawiska, procesy, tendencje, Lublin, s. 191-204.

Erova S. N., 2007, Istorija zaimstvovanij slov v russkom jazyke, w: Učenye zapiski, vyp. 2(51), Hudžand, s. 155-160.

Komorowska H., 2003, Metodyka nauczania języków obcych, Warszawa.

Krajka J., 2016, Czy korpus prawdę Ci powie? O wykorzystaniu korpusów w nauczaniu języka do celów zawodowych, , Języki Obce w Szkole”, nr 3, s. 34-38.

Krysin L. P., 1996, Inojazyčnye slova v sovremennoj žizni, Moskva.

Krysin L. P., 2004, Russkoe slovo, svoe i čužoe: Issledovanija po sovremennomu russkomu jazyku i sociolingvistike, Moskva.

Luciński K., 2000, Anglicyzmy w języku polskim i rosyjskim, Kielce.

Mańczak-Wohlfeld E., 2006, Angielsko-polskie kontakty językowe, Kraków.

Nowy stownik poprawnej polszczyzny PWN, 1999, A. Markowski (red.), Warszawa.

Seretny A., Lipińska E., 2005, ABC metodyki nauczania języka polskiego jako obcego, Kraków.

Stownik informatyczny angielsko-polski, 1991, A. Marciniak., M. Jankowski (red.), Warszawa -Poznań.

Šanskij N. M., 2009, Leksikologija sovremennogo russkogo jazyka, Moskva.

Walczak B., 1987, Między snobizmem i moda, a potrzebami języka, czyli o wyrazach obcego pochodzenia w polszczyźnie, Poznań.

Witaszek-Samborska M., 1992, Wyrazy obcego pochodzenia we współczesnej polszczyźnie, Poznań.

\section{Źródla internetowe}

Analizy i raporty / Cudzoziemcy pracujący w Polsce - statystyki, www.mpips.gov.pl/analizy-i-raporty/cudzoziemcy-pracujacy-w-polsce-statystyki/ [4.04.2018].

www.bankier.pl/wiadomosc/Cudzoziemcy-w-Polsce-przybywa-informatykow-medykow-i-specjalistow [4.04.2018].

www.rp.pl/artykul/1122154-Brakuje-informatykow--Deficyt-siega-50-tys--specjalistow [4.04.2018].

https://www.computerworld.pl/slownik [1.04.2018]

https://greenforest.com.ua/journal/read/osoblivosti-anglijskoi-u-galuzi-it [2.04.2018] 


\title{
Viktoriia Hudy
}

\section{IS RUSSIAN MORE "ENGLISH” THAN POLISH? ABOUT ENGLISH BORROWINGS IN THE LANGUAGE OF INFORMATION TECHNOLOGY FROM THE PERSPECTIVE OF TEACHING POLISH AS A FOREIGN LANGUAGE}

Keywords: specialist language, borrowings, language of information technology

\begin{abstract}
Due to globalization professionals in different fields of knowledge, especially those who are highly-skilled, may easily find employment beyond the borders of their own countries. Poland is one of the countries, where the labor market is getting more and more attractive to foreigners. It is also the case for the IT sector that for years has attracted specialists from the countries of the former Soviet Union. Therefore, it seems to be interesting to compare the influence of English, which is the base of the specialist language in this sector, on the Polish and Russian languages.

In this paper, the author answers the question whether English borrowings in the Polish and Russian language of information technology are the same. The author shows the degree of assimilation of exemplary loan words in both languages under discussion and presents the resulting implications for teaching Polish as a foreign language.
\end{abstract}

